\title{
Libraries and Reading
}


This page intentionally left blank 


\section{Libraries and Reading: Intellectual Disability and the Extent of Library Diversity}

BY

MATTHEW CONNER

University of California, Davis, USA

LEAH PLOCHARCZYK

Florida Atlantic University, USA

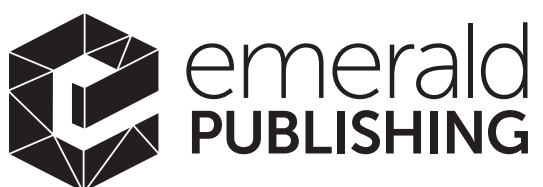


Emerald Publishing Limited

Howard House, Wagon Lane, Bingley BD16 1WA, UK

First edition 2020

Copyright (C) 2020 Emerald Publishing Limited

\section{Reprints and permissions service}

Contact: permissions@emeraldinsight.com

No part of this book may be reproduced, stored in a retrieval system, transmitted in any form or by any means electronic, mechanical, photocopying, recording or otherwise without either the prior written permission of the publisher or a licence permitting restricted copying issued in the UK by The Copyright Licensing Agency and in the USA by The Copyright Clearance Center. Any opinions expressed in the chapters are those of the authors. Whilst Emerald makes every effort to ensure the quality and accuracy of its content, Emerald makes no representation implied or otherwise, as to the chapters' suitability and application and disclaims any warranties, express or implied, to their use.

\section{British Library Cataloguing in Publication Data}

A catalogue record for this book is available from the British Library

ISBN: 978-1-78973-386-0 (Print)

ISBN: 978-1-78973-385-3 (Online)

ISBN: 978-1-78973-387-7 (Epub)

ISOQAR certified

Management System

awarded to Emerald

for adherence to

Environmental

standard

ISOQAR ISO 14001:2004. 


\section{Matt's Dedication}

To my parents for their endless support and example, and to my mom who planted the seed of special education long before I was aware of it.

\section{Leah's Dedication}

To my parents for their love, support, encouragement, and endless sacrifice.

To my book club buddies for their inspiration, wisdom, and great gusto for life. You have opened my eyes and changed me in ways you will never know. You are all extraordinary individuals. Never let anyone tell you that you can't, and never give up...never.

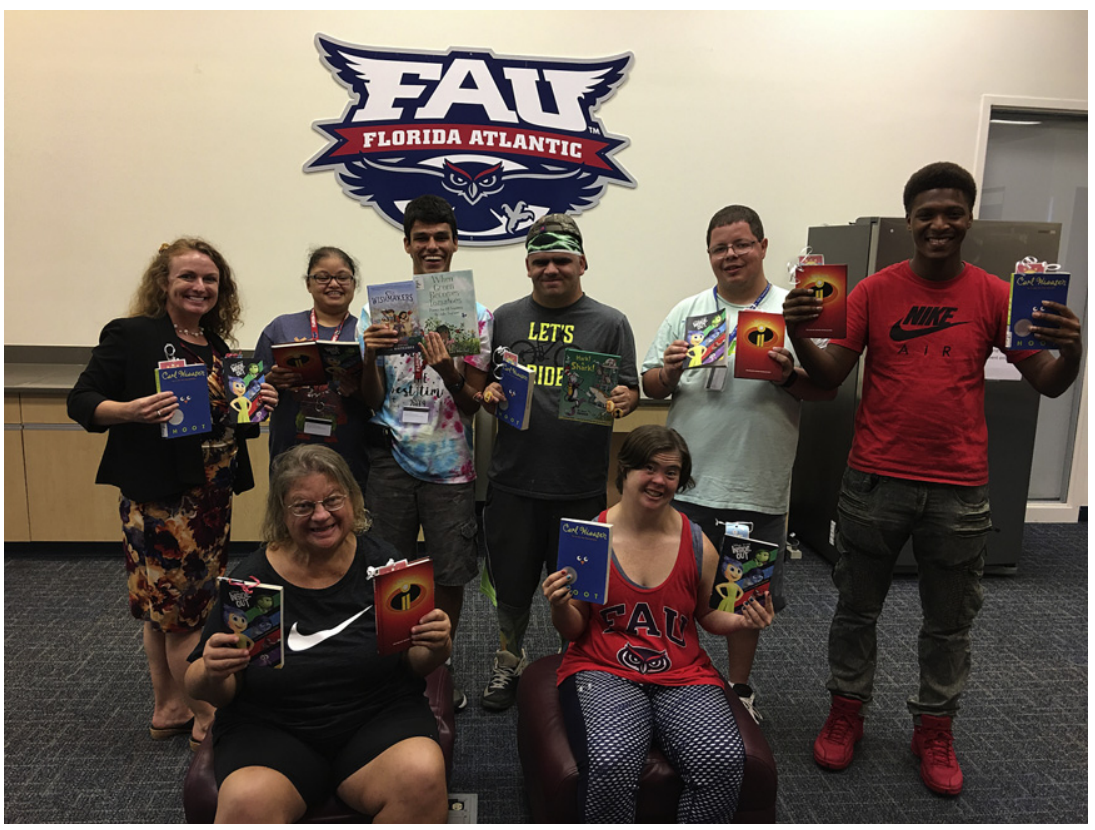


This page intentionally left blank 


\section{Table of Contents}

Preface ix

Acknowledgments $x i$

Introduction 1

Chapter 1 The History of Libraries and Literacy in the United States $\quad 7$

Chapter 2 Current Issues of Persons with ID and New Approaches 29

Chapter 3 Educational Theory and Individuals with ID 57

Chapter 4 Case Studies of Book Clubs for Individuals with ID in Academic and Public Libraries 85

Chapter 5 Social Justice, Individuals with ID, and Librarianship 111

$\begin{array}{ll}\text { References } & 143\end{array}$

$\begin{array}{ll}\text { Index } & 163\end{array}$ 
This page intentionally left blank 


\section{Preface}

A word is in order about the serendipitous origins of this project. Matt had recently published The New University Library (2014) with the American Library Association (ALA). This book grew out of his work for the Librarians Association of the University of California (LAUC), the professional association of librarians at the University of California, on which he had served in various capacities, culminating in the presidency. As with the rest of the profession, LAUC was concerned about the future of libraries. A system-wide conversation on this topic was extended into the book which surveyed historical trends and applied them to case studies both inside and outside of the University of California.

Following publication, Matt attended a conference at the University of Illinois at Urbana-Champaign, one of the book's case studies, at the invitation of some of the staff. With the book published, it remained to be seen if its predictions would come true, and he recalled a study that found that a high percentage of futurists were wrong. At this conference, he met Leah who was giving a poster on an outreach program by the library at Florida Atlantic University (FAU). One of the conclusions of The New Library is that outreach would be important for libraries as they redefine themselves and reach out to new audiences, and Leah had taken a particular interest in outreach at her library. One of her projects is the basis of this study: the use of a book club in an academic library to advance the educational goals and college experience of students with intellectual and developmental disabilities (IDD). It seemed to Matt that this was more than another clever idea for reaching its participants. It had implications for the entire profession in policy, goals, service mission, and selfdefinition. As the project unfolded, it became clear to both authors that the serendipity of their meeting ran even deeper than had appeared. Individuals with ID, as will be seen, have a complex history with libraries. (We will use the abbreviation ID as a shorthand for the longer abbreviation and because intellectual disabilities were a universal characteristic of the populations we studied while developmental disabilities were uncommon.) Associated with the literacy efforts of public and school libraries, students with ID have not had a presence in higher education until recently. This came about through a relatively new movement called, Post-Secondary Education (PSE) which defines adults with ID as part of continuing education which gives nontraditional students access to college classes. It is only because one such program exists at Leah's campus that she was able to develop the book club at all. 
The authorial partnership is not only reflected in the book's original circumstances but in the methodology by which it went forward. In a time of organizational change, librarians have become familiar with the terms "top-down" and "bottom-up" as ways of structuring projects. The first refers to developing a plan at the administrative level and executing it. The second refers to the opposite process where the initiative comes from the lower levels of an organization, either through ideas from staff or practices that coalesce into policy. The choice of starting above or below depends on the circumstances, and it is not uncommon for both to be employed simultaneously. That is the case here by virtue of the authors' history. The policy issues and professional trends of Matt's book illuminated Leah's case study, and her innovations shed new light on trends. The two perspectives worked in synergy. While theory and practice are supposed to be interdependent, the scientific method formulates theory as preceding experiment. So, it is worth noting that this project has operated somewhat in reverse with the practice of the library book club at FAU in robust form before coming under examination by theory. The precedence of practice over theory recurs throughout our study.

Far from resolving all the issues presented, our study often only introduces them. But it is our hope that this book will reduce the chance and serendipity that brought it about and smooth the path of others toward understanding and contributing to library services for disability. 


\section{Acknowledgments}

Our wide-ranging journey in this book would not have been possible without the aid of a long list of people who gave us a warm welcome when we arrived at their shores. Their generosity and dedication are deeply appreciated and give us high hopes for the future of libraries and disability services.

We first offer our sincerest thanks to Emerald Publishing and to our very supportive editors, Charlotte Maiorana, Charlie Wilson, and Nick Wolterman for taking a chance on us and this project. It was a pleasure to work with each of them, and we hope they enjoy the finished product!

We also thank Dr. Mary Louise Duffy for reaching out to the library staff years ago to suggest that the library host an intern from the program. If not for her wisdom, expertise, support, edits, and suggestions for the book, and for her time "lunching and learning" to teach us about exceptional education and what it means to work with adults with ID, this project would have been impossible. Her funny stories will be remembered and her friendship will be missed. We hope her retirement from FAU is going splendidly. Many thanks, as well, to Dr. Michael Brady, Dr. Gwen Carey, Professor Angelica Downey, Dr. Melody Wright, Ms. Heather Graeve, and everyone in the ACI program who gave of their time and energy toward this project. Without the support of the Academy for Community Inclusion (ACI) and its many wonderful professors, staff members, peer mentors, and students, none of this would have been possible. We are indebted to each and every one of you.

We thank Dr. Tom Fish, President and founder of NCBC, Lyna Smith, Susan Berg, Rachel Staley, Marilyn Darrow, and all of NCBC staff with whom we worked closely throughout this project. They answered questions, sent resources, provided stats, and trained us as NCBC affiliates. NCBC is a wonderful and unique organization, and we feel lucky that the FAU book club can contribute as one of its affiliates.

We thank Miss Mattie Rials, Laura Stokes, Darlene Morgan, Scooter Mouse, the staff of the McComb Public Library, and the Wednesday Special Friends who shared their warm Southern hospitality and welcomed us into their family. They hold a special place in our hearts and will never be forgotten.

We thank Dr. Meg Grigal and Debra Hart of Think College! for their inspirational and transformative research on Post-Secondary Education (PSE) Programs for college students with ID. We relied upon their expertise and vast knowledge of PSE throughout the writing of this book. 
At the MacArthur Library at FAU, the site of the FAU book club, Leah particularly wishes to thank and acknowledge her co-facilitators and coders, Marilee Brown and Linda Lesperance for keeping her sane, and for their contributions, patience, time, energy, superb organizational skills, and most of all for their sense of humor to pull off something memorable. She hopes they enjoyed the ride as much as she did. Thanks also goes to Raven Mello, Ashlee Malkin, Hope Wiersma, Miranda Jones, and Sibel Bode, student staff at the MacArthur Library and peer mentors who took time out of their busy college lives to attend book club and to assist with the facilitation, reading and game playing. Everyone was integral to the smooth operation of the book club and their efforts do not go unnoticed. Leah particularly thanks Edith (Cookie) Davis, staff at the MacArthur Library, for her flexibility with her schedule and for constantly rearranging her desk duty so that Marilee, Linda, and Leah could run book club. Her keen searching skills and her assistance with fact finding and checking the library literature was a lifesaver. She is a true asset to the library team, and we are lucky to have her. And we thank Diane Arietta for the time she spent setting up our "movie theater" in the back staff area so that the book club could enjoy our end of the semester celebrations, and an even bigger thank you for her patience during the celebrations!

We thank Donna Simonovitch, Danae Montgomery, and Ximena Levy at FAU's Research and Integrity Office for their patience in answering Leah's countless questions via telephone and email. She could not have made it through the Institutional Review Board (IRB) process without them.

In the FAU Administration, we thank Ethan Allen for his encouragement, support, and for taking so much time with Leah to get our IRB proposal and application just right. He went above and beyond the call of duty in helping us to get our research project approved. Thanks to Dean Carol Hixson and the FAU Library Leadership Team for taking the time to listen to Leah's pitch and for approving and offering financial assistance so that the MacArthur Campus Library could become one of the very first academic libraries trained as an NCBC affiliate. Without their support and encouragement, Leah and her co-facilitators could not have undergone the training necessary to complete the affiliation process. Leah thanks Dean Hixson, too, for encouraging her to test her leadership skills and for allowing her to continue with a fulfilling project that gives her great professional joy.

We thank all of the coordinators and facilitators of the NCBC affiliates located throughout the United States and as far reaching as Australia who so generously gave up their time to speak to Leah and participate in interviews both over the phone and via email. Leah enjoyed speaking to each and every one of them and learned so much about how to successfully run a book club for individuals with ID. Leah enjoyed their stories and appreciates the support they offered by sharing resources, book selections, and other pieces of advice that she used in her club to make it the most positive experience possible. Although they were strangers to her when she first reached out to them, she is reminded of how supportive and giving the library world can be. She feels proud to call them colleagues. 
We thank Mrs. Pyle, Mrs. Weichel, Ms. Ettiene, and Mrs. Orofino for taking the time to answer survey questions and for offering words of encouragement and for letting Leah know that she was on the right track. Working with their sons and daughters is pure joy for her.

We have many debts to the University of California, Davis, Library. We thank the library's Instructional Planning Group for commenting on the manuscript and especially librarians, Amy Bush for expert commentary on educational scholarship, Alesia MacManus for her insightful editing, and Erik Fausak for showing us how powerful systematic studies can be outside of their traditional domain of medical research. We wish to thank Nancy Ervin, Operations Supervisor at the Carlson Health Sciences Library, for her crucial work in bringing the Human Library project to UC Davis, her organizational abilities in administering it, and for editing and contributing to the manuscript.

We are deeply grateful to Michele Tobias, GIS Data Curator, for her extraordinary GIS skills, generosity, and imagination in bringing the great power of this field of study to our project. We also thank Vessela Ensberg, Associate Director of the Data Management Department, for not only her advice on data management but on study design out of her extensive scientific training.

We thank Leon Chai, Professor Emeritus of English at the University of Illinois at Urbana-Champaign, Matt's dissertation director and friend, for his never-failing generosity and intelligence in critiquing our manuscript and for his longtime support that made this professional accomplishment possible.

We thank Michael and Jamie Berube, as well as their immediate family, for their heroic and inspirational story, and we particularly thank Michael for his contributions to disability studies and his generosity in reviewing the manuscript and giving helpful suggestions.

Thanks goes to Ron Stoner, Professor Emeritus of Physics from Bowling Green State University, for his vast scientific knowledge and his great versatility and intelligence in applying it to any problem. We are deeply grateful for his suggestions on where and how to apply quantitative analysis to our results.

We thank John Conner for reading every one of our chapters and providing valuable feedback, and we thank Chin Conner for permission to reference her inspirational master's thesis.

Leah also wishes to give personal acknowledgments. Thanks to Dr. Erin Burns-Davies, Dr. Shireen Lalla, and Ms. Emily Meade who are some of the smartest women I know and provide inspiration to me every single day. I thank them for always believing in me and for always being there. The friendship they give knows no bounds.

Thank you to my little sister, Dr. Beth Plocharczyk, for setting the bar high. I admire her bravery, hard work ethic, endless energy, and intelligence. I look at all that she has achieved in life and it makes me want to do and be better. (I bet she never thought I'd be authoring a book!)

A heartfelt thank you goes out to my parents, Judy and Stan, for being exemplary role models. From a young age, they taught my sister and me the value of a hard day's work. But more than that, they taught us that the most important thing in life is to give selflessly to others and to practice patience, kindness, and 
empathy. No matter what I attempted to do growing up, and even today, they encouraged me and believed in me. They built for me a strong foundation, and I am lucky to have them as parents. I hope that I have made them proud.

And finally, thank you to all of my remarkable book club buddies (including service dogs, Clay and Roxi). I have had the pleasure of meeting over the years, some briefly, and some whom I have grown to know quite well. Without them, none of this would be possible. I feel grateful to call them my friends. They made me laugh, and even cry (tears of joy and pride.) Each of them demonstrates the true meaning of perseverance, and the life lessons that they taught me are invaluable. I look forward to many more book club sessions spent with them now and in the future. Thank you. 